\title{
Comparative analysis of heavy metals in hair and nail samples of drug-addicted patients in relation with water intake facilities
}

\author{
Inzamam ul Haq ${ }^{1}$, Anchal Romaan*2 and Tahmina Gulzar ${ }^{3}$ \\ ${ }^{1}$ Department of Chemistry, Government College University, Lahore \\ ${ }^{2,3}$ Department of Zoology, Wildlife, and Fisheries, University of Agriculture, Faisalabad \\ *Corresponding Author”s Email: anchal.romaan@gmail.com
}

\begin{abstract}
The current study was conducted to detect the bioaccumulation of heavy metals ( $\mathrm{Fe}, \mathrm{Zn}, \mathrm{Cr}, \mathrm{Cd}, \mathrm{Pb}$, and $\mathrm{Hg}$ ) in relation to drinking water facilities in Lahore, Pakistan. Hair and nail samples were used as a biological indicators. The study comprises two types of the population a) drug-addicted patients, drinking Tap water, and b) the control group using filtered water for many years. Water samples were collected from three sites; Minar-e- Pakistan, Data Darbar, and Chouburji in Lahore, Pakistan. Nails and hair samples were collected from drug-addicted subjects $(n=15)$ and healthy ones as the control group $(n=15)$. A quantitative determination of heavy metals was made by using Flame Atomic Absorption Spectrometry (AAS). Average values for metals in water samples were present in decreasing order like Zinc > Iron > Lead > Chromium > Cadmium > Mercury. A similar tendency was observed for biological samples (hair and nails) collected from two groups of people, including drug-addicted patients. Mean values of heavy metals calculated for drug-addicted patients were significantly higher than those of healthy ones (control group), indicating that contaminated water contributes to heavy metals accumulation and toxicity in the human body. The concentration of heavy metals in samples was higher than permitted levels recommended by Pakistan Environmental Protection Agency and World Health Organization. This study recognized the factors responsible for the deposition of heavy metals in drug-addicted patients and the requirements to trim down heavy metals in water. Conclusively, water filtration plants must be implemented at the macro level to prevent the bioaccumulation of metals into the human body.
\end{abstract}

\section{Keywords: heavy metal, drinking water, groups of people, AAS}

\section{Highlights}

- Nail and Hair samples were collected from drug-addicted patients from different areas of Lahore.

- Samples were processed and analyzed to determine the bioaccumulation of heavy metals for water intake facilities.

- Comparative analysis of experimental and controlled groups showed that water intake facilities were directly responsible for the bioaccumulation of heavy metals.

\section{Introduction}

The natural aquatic sources in Pakistan have become a victim of metallic pollution due to untreated industrial effluents, agriculture runoff, and domestic sewage (Chao et al., 2014). Heavy metals are those species having atomic mass 5 times greater than that of water. Their density is higher than $5 \mathrm{~g} \mathrm{~cm}^{-3}$ (Abdelateyet al., 2011). There are two significant causes of heavy metals, Natural phenomena such as volcanic eruption, weathering processes, and biological issues that introduce toxic metals in the environment. Anthropogenic sources like industrialization, fossil fuel burning, untreated domestic waste, refining of ores, food manufacturing, and cosmetics are other significant factors contributing to toxic metals accumulation in the food chain (Chen et al., 2005).

Water distribution systems (WDS) release toxic heavy metals in the potable water, which is responsible for metal bioaccumulation in living organisms (Alabdula'aly and Khan, 2009). Metal poisoning has been described as a "silent epidemic" for health issues. Trace elements show detrimental effects on the human body when they exceed their normal range (Apostoli, 2002; Gautam et al., 2014).

The introduction of toxic heavy metals in potable water is considered a risk to human health. Almost $90 \%$ of bioaccumulation of heavy metals in the body is made by water and food contaminated with heavy metals (Loutfyet al., 2006). Biochemically, living organisms cannot degrade toxic heavy metals and finally accumulate up to dangerous levels (Rehman et al., 2018). Biomonitoring is the standard tool for the estimation of metallic contamination (Stepanova et al., 
2018). Fibrous proteins having $\alpha$-keratins are an integral part of human hair and nail tissues; they have strongly affected mineralization in the body. However, blood and other fluids show transitory absorption of heavy metals, but hair and nails reflect apparent indications of metallic content (Barbosa et al., 2005). Heavy metals, including lead (Pb), Cadmium (Cd), Copper $(\mathrm{Cu})$, Cobalt $(\mathrm{Co})$, and Zinc $(\mathrm{Zn})$, absorb in the fingernails by various means as well as a water source (Kumar et al., 2013). Metals can be 200-300 times more highly deposited in hair than blood and considered "Biological records" of the body. Usually, mineral metabolism occurs in the human body, which is indicated by hair sample analysis through hair excretory product accumulation. Their depositions illustrate a slight association to the varying levels in other body tissues (Kaluza et al., 2000). It is documented that keratin which comprises human hair, contains almost 14\% cysteine (amino acid). Elements present in hair tissues are attached with S from amino acids, including cysteine, to induce metalloproteins (Chatt, 1988). Metallic ions show greater affinity with melanin integrated into the hair, and ionic biding is enhanced by attractive forces like van der Waal's forces (Srogi, 2006).

Mammalian nails are considered to have modified epidermis (appendages) consisting of four parts; nail bed, nail matrix, nail fold, and nail plate (Haneke, 2015). Nails after development are considered an excellent reflection of longlasting exposure to heavy metals (Ibrahim et al., 2014). Fingernails grow at the rate of 05-1.2 mm in a week, whereas toenails' growth rate is slow, approximately $30-50 \%$, providing a more extended interaction period for minerals. However, Nails and hair are preferred for bio-monitoring due to their storage convenience, ease of collection, ease of handling. They do not need any sophisticated condition compared to body fluids sensitive to contaminations and, more significantly, their worth in evaluating the exposure of metals and accumulation in the body. The present research was deliberated to evaluate the concentration of heavy metals in water sources meant for specific areas of Lahore and their accumulation in hair and nail samples for establishing a potential correlation among these toxic heavy metals and drinking water facilities.

\section{Materials and Methods}

\subsection{Sampling site and study area}

Three specific areas of Lahore were selected for this study, (1) Minar-e-Pakistan, (2) Choburji, and (3) Data Darbar. The drug-addicted patients consumed tab water fixed along the streets; the control (unexposed) group consisted of hostel residents consuming reverse osmosis treated water. All concerned persons were Male, 20-40 years old. The total number of samples for nails and hair was 30, out of which 15 for Drug addicted patients and 15 for the Control Group.

\subsection{Collection and Storage of Hair and nail Samples}

Scalp hair examining techniques can influence the hair metal content. The trimming gadgets may add certain metals to hair; scissors made of mild steel may contribute Fe, while tempered steel scissors may include $\mathrm{Cr}$ in the hair (Rodrigues et al., 2008). Around $1 \mathrm{~g}$ of scalp hair samples was trimmed from the sub-occipital zone of the head at $1 \mathrm{~cm}$ from the scalp as 3-4 $\mathrm{cm}$ long strands with the assistance of a couple of plastic scissors (China) by using gloves. Then, samples were moved into pre-cleaned zip-mouthed polythene packs appropriately tagged. This strategy was chosen to gather scalp hair samples in the present examination since it limits the danger of outer defilement (Qayyum and Shah, 2014). The examples were put away independently in fixed marked plastic packs at room temperature before additionally handling (Qayyum and Shah, 2014). Similarly, nail clippings were gathered from each of the ten fingers and toes, considered probably undertaking the accumulation of metallic content in them (Yoshizawa et al., 2002).

\subsection{Washing of Scalp Hair Samples}

The hair samples were put in the conical flasks $(250 \mathrm{~mL})$, to which $50 \mathrm{~mL}$ of $5 \%(\mathrm{w} / \mathrm{v})$ cleanser was included. After this, the samples were left undisturbed for $2 \mathrm{hr}$. followed by washing with purified water until all the cleanser was drained out. A short time later, the samples were washed with an abundance of distilled water. At last, the samples were dried in an electric stove medium-term at $70^{\circ} \mathrm{C}$ and cooled to room temperature in desiccators containing silica gel as the desiccant (Qayyum and Shah, 2014).

\subsection{Washing of Nail Samples}

The nail samples were placed in named conical flasks and absorbed by 5\% (w/v) cleanser solution overnight to debilitate the bound soil. Any inexactly bound pollution was evacuated physically at this stage. Acetone (50 mL) was then added to the conical flasks containing the nail samples.

\subsection{Digestion of Scalp Hair Samples}

A precisely measured amount of dried hair test $(\sim 1.000 \mathrm{~g})$ was set in a conical flask $(250 \mathrm{~mL})$. The samples were treated with $10 \mathrm{~mL}$ of concentrated $(65 \%) \mathrm{HNO}_{3}$ and warmed at $80^{\circ} \mathrm{C}$ for around 60 concentrated $(70 \%) \mathrm{HCLO}_{4}$ with ensuing warming to a clear bubble until the point that thick white vapor appeared, identifying the end of the procedure. The sample was again cooled to room temperature. The processed sample was replaced with a flask, and the last volume (50 
$\mathrm{mL}$ ) was made up of $0.1 \mathrm{~N} \mathrm{HNO}_{3}$. A control experiment was additionally run similarly. After diluting the mixture, the solution was coded and put away in plastic jars (Qayyum and Shah, 2014).

\subsection{Digestion of Nail samples}

A precisely measured amount of dried nails test $(\geq 0.100 \mathrm{~g})$ was set in a conical flask. At that point, $10 \mathrm{~mL}$ of concentrated $\mathrm{HNO}_{3}$ and $\mathrm{HCLO}_{4}(5: 1, \mathrm{v} / \mathrm{v})$ was added to the flasks containing nails. This sample was left undisturbed for 30 minutes at room temperature. In the wake of predigesting at room temperature, the nail sample was warmed for 1 hour at $80^{\circ} \mathrm{C}$ on a hotplate until the point when thick white exhaust advanced. The sample was again cooled to room temperature. The processed example was exchanged to a volumetric cup, and the last volume $(25 \mathrm{~mL})$ was balanced with $0.1 \mathrm{~N}$ of $\mathrm{HNO}_{3}$ (Qayyum and Shah, 2014).

\subsection{Digestion of Water sample}

$50 \mathrm{~mL}$ of water sample was taken fitted with a reflux cap followed by adding $1 \mathrm{~mL}$ concentrated $\mathrm{HNO}_{3}$ and $0.5 \mathrm{~mL}$ hydrochloric acid in each flask containing $50 \mathrm{~mL}$ of water samples. Samples were then digested, keeping temperature 95 ${ }^{\circ} \mathrm{C}$ for about 2.5 hours, and covered with aluminum foil. Temperature is strictly maintained at $95{ }^{\circ} \mathrm{C}$. About 2.5 hours later, samples were removed from the heating source and kept for 30 minutes. Aluminum foil was removed, and $50 \mathrm{ml}$ of deionized water was added. Flasks were shaken well and stored for AAS analysis.

\subsection{Quantification of Metals by Atomic Absorption Spectrometry}

Atomic Absorption spectrometry (AAS) was used to investigate metallic content in water, nail, and hair samples (Apostoli, 2002).

\section{Results and discussion}

Atomic absorption spectroscopy was applied to detect heavy metals in the hair and fingernails of the group of people targeted to analyze heavy metal bioaccumulation related to drinking water(Rodushkin and Axelsson, 2000). The trend of descending positions of heavy metals ( Table 1) in the water sample showed that zinc $(\mathrm{Zn})$ is present in the highest amount and mercury $(\mathrm{Hg})$ in the lowest amount among all selected Heavy metals $(\mathrm{Zn}>\mathrm{Fe}>\mathrm{Cr}>\mathrm{Pb}>\mathrm{Cd}>\mathrm{Hg})$. $\mathrm{Zn}$ concentration is reported much higher in tap water, which may be linked to the discharge of $\mathrm{Zn}$ from piping and fittings. While drinking water usually contributes a negligible content of $\mathrm{Zn}$ intake except for elevated $\mathrm{Zn}$ levels encounters due to corrosion of piping and fittings (Agrawal et al., 2010), which is similar to the earlier reports of (Chowdhury et al., 2016). The concentration of metals in water sources is above the standard values recommended by WHO (Fig.1). The contamination in drinking water may result in serious health issues of the nervous system, kidneys, cancer, diabetes, and cardiovascular diseases (Rehman et al., 2018; Mohod et al., 2013).

Table 1: Distribution of Selected Metals in Experimental water samples (mg/L)

\begin{tabular}{|c|c|c|c|c|c|c|c|}
\hline Sr. No & $\begin{array}{c}\text { Sample } \\
\text { ID }\end{array}$ & $\mathbf{C d}$ & $\mathbf{Z n}$ & $\mathbf{C r}$ & $\mathbf{P b}$ & $\mathbf{F e}$ & $\mathbf{H g}$ \\
\hline $\mathbf{1}$ & $\begin{array}{c}\text { Minar e } \\
\text { Pakistan }\end{array}$ & 0.004 & 4.329 & 0.383 & 0.434 & 1.529 & 0.003 \\
\hline $\mathbf{2}$ & $\begin{array}{c}\text { Data } \\
\text { Darbar }\end{array}$ & 0.005 & 4.934 & 0.463 & 0.410 & 1.371 & 0.001 \\
\hline $\mathbf{3}$ & chouburji & 0.006 & 5.763 & 0.490 & 0.298 & 0.803 & 0.002 \\
\hline & Average & 0.005 & 5.008 & 0.445 & 0.380 & 1.234 & 0.002 \\
\hline
\end{tabular}




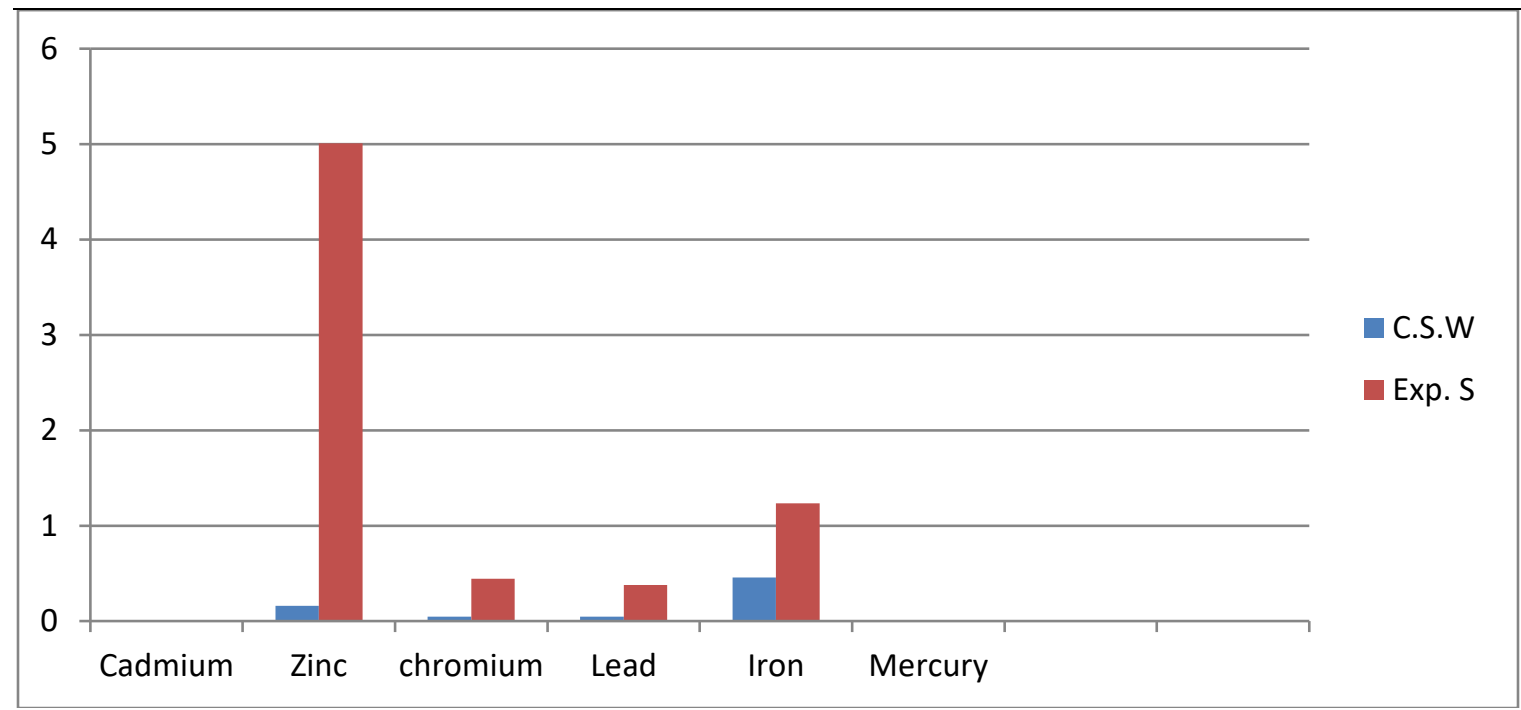

Figure 1: Graphical illustration of Comparisons between Selected Metal Levels in control water samples and Experimental water samples

$*$ C.S.W > control sample of water; *Exp.s> Experimental samples

Comparison of Selected Metal Levels in the control group and hair samples of Drug-Addicted Patients

Comparison of average values $(\mathrm{Fe}, \mathrm{Cd}, \mathrm{Hg}, \mathrm{Zn}, \mathrm{Cr}$, and $\mathrm{Pb}$ ) in the hair samples of Drug addicted subjects showed a slightly higher level than a control group (Table 2). While examining the scalp hair of Drug addicted patients, $\mathrm{Zn}(40.42 \mathrm{mg} / \mathrm{L}) \mathrm{has}$ appeared as highest on average, followed by $\mathrm{Fe}(30.99 \mathrm{mg} / \mathrm{L}$ ) (Fig.2). While $\mathrm{Pb}, \mathrm{Cr}, \mathrm{Cd}$, and $\mathrm{Hg}$ revealed relatively lower mean levels at $1.00,0.49,0.41$, and $0.280 \mathrm{mg} / \mathrm{L}$, respectively. Overall, the declining trend in average metal altitudes in the scalp hair of healthy donors showed the resulting sequence: $\mathrm{Zn}>\mathrm{Fe}>\mathrm{Pb}>\mathrm{Cr}>\mathrm{Cd}>\mathrm{Hg}$. These results are per the investigation of Ibrahim et al. (2014). Bioaccumulation of heavy metals in hair and nails is directly related to the environment and dietary habits (Abdulrahman et al., 2012). Analysis of metals from hair and nail samples could be a helpful strategy for early screening of the disease and cancer risks (Golasik et al., 2015).

Table 2: Comparison of Selected Metal Levels (mg/L) in control Hair samples and Hair samples of Drug-Addicted Patients

\begin{tabular}{|c|l|l|l|l|l|l|l|}
\hline Sr. No & Sample ID & \multicolumn{1}{|c|}{ Cd } & \multicolumn{1}{|c|}{$\mathbf{Z n}$} & $\mathbf{C r}$ & \multicolumn{1}{|c|}{ Pb } & $\mathbf{F e}$ & $\mathbf{H g}$ \\
\hline 1 & D.P.H.1 & 0.44 & 41.55 & 0.51 & 1.03 & 32.81 & 0.284 \\
\hline 2 & D.P.H.2 & 0.39 & 37.32 & 0.49 & 1.09 & 33.98 & 0.265 \\
\hline 3 & D.P.H.3 & 0.38 & 39.06 & 0.53 & 0.98 & 30.23 & 0.270 \\
\hline 4 & D.P.H.4 & 0.48 & 41.03 & 0.49 & 0.90 & 29.03 & 0.290 \\
\hline 5 & D.P.H.5 & 0.42 & 42.06 & 0.46 & 0.99 & 29.93 & 0.305 \\
\hline 6 & D.P.H.6 & 0.50 & 41.94 & 0.56 & 1.09 & 30.09 & 0.298 \\
\hline 7 & D.P.H.7 & 0.43 & 40.54 & 0.40 & 0.93 & 31.04 & 0.304 \\
\hline 8 & D.P.H.8 & 0.41 & 42.67 & 0.47 & 0.98 & 28.06 & 0.280 \\
\hline 9 & D.P.H.9 & 0.39 & 37.89 & 0.48 & 1.08 & 32.09 & 0.312 \\
\hline 10 & D.P.H.10 & 0.36 & 38.05 & 0.52 & 1.12 & 31.08 & 0.209 \\
\hline 11 & D.P.H.11 & 0.45 & 41.38 & 0.49 & 0.89 & 29.04 & 0.227 \\
\hline 12 & D.P.H.12 & 0.41 & 42.08 & 0.51 & 0.93 & 27.99 & 0.372 \\
\hline 13 & D.P.H.13 & 0.44 & 39.85 & 0.50 & 1.05 & 34.00 & 0.205 \\
\hline 14 & D.P.H.14 & 0.36 & 40.03 & 0.49 & 1.09 & 30.23 & 0.301 \\
\hline 15 & D.P.H.15 & 0.40 & 40.95 & 0.53 & 0.99 & 29.07 & 0.298 \\
\hline
\end{tabular}

*D.P.H> Drug Addicted Patient's Hair Sample 


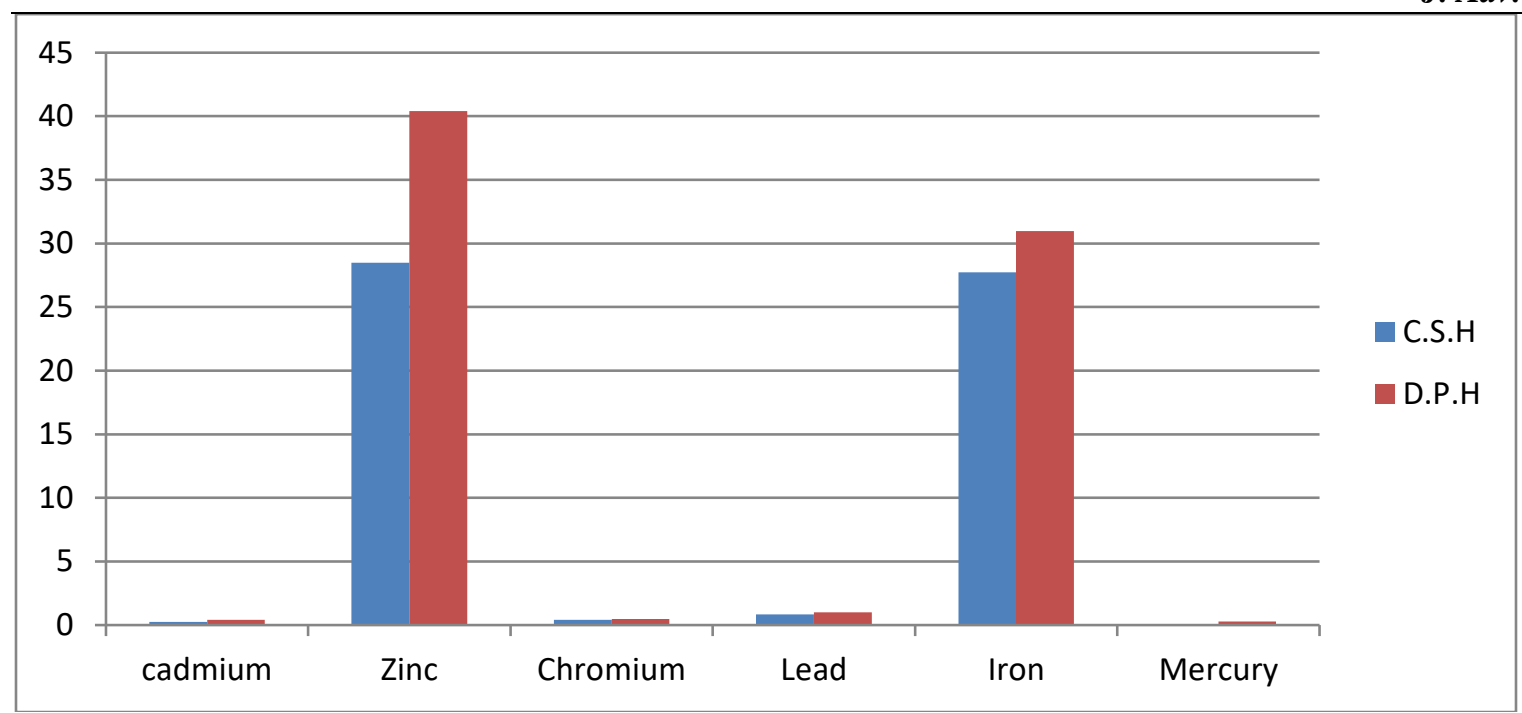

Figure 2: Graphical illustration of Comparisons between Selected Metal Levels in control Hair samples and Hair samples of Drug-Addicted Patients

*D.P.H $>$ Drug Addicted Patient's Hair Sample; *C.S.H> control samples of hair

Comparison of Selected Metal Levels in control Nail samples and Nails samples of Drug-Addicted Patients

Generally, the sequence of metal accumulation in the nails of Drug addicted patients (D.P.N) was observed as; $\mathrm{Zn}>\mathrm{Fe}$ $>\mathrm{Pb}>\mathrm{Cr}>\mathrm{Cd}>\mathrm{Hg}$ (Table 3). While $\mathrm{Zn}(41.44 \mathrm{mg} / \mathrm{L})$ emerged as the dominant on average, followed by $\mathrm{Fe}(38.90 \mathrm{mg} / \mathrm{L})$, Lead, Chromium, Cadmium, and Mercury exposed relatively lower mean levels 1.32, 0.38 and 0.27 and $0.114 \mathrm{mg} / \mathrm{L}$, accordingly. $\mathrm{Zn}, \mathrm{Fe}, \mathrm{Pb}, \mathrm{Cd}, \mathrm{Cr}, \mathrm{Hg}$ showed the following values for metals accumulation 42.46, 42.66, 1.4, 0.38, 0.51, and $0.11 \mathrm{mg} / \mathrm{L}$, respectively. Analysis of the samples collected from Drug addicted patients showed significantly high bioaccumulation of metals related to their unclean drinking water, as reported earlier(Bibi et al., 2016). The current results order was calculated as $\mathrm{Pb}>\mathrm{Cr}>\mathrm{Cd}$ in nail samples of Lahore individuals. Anthropogenic sources add heavy metals to the environment causing a toxic effect on living organisms (Bibi et al., 2016).

Table 3: Distribution of Selected Metals in Nails of D.P.N $(\mathrm{mg} / \mathrm{L})$

\begin{tabular}{|c|l|l|l|l|l|l|l|}
\hline Sr. No & Sample ID & \multicolumn{1}{|c|}{$\mathbf{C d}$} & \multicolumn{1}{|c|}{$\mathbf{Z n}$} & $\mathbf{C r}$ & \multicolumn{1}{c|}{$\mathbf{P b}$} & $\mathbf{F e}$ & $\mathbf{H g}$ \\
\hline 1 & D.P.N.1 & 0.42 & 45.70 & 0.53 & 1.20 & 44.29 & 0.109 \\
\hline 2 & D.P.N.2 & 0.40 & 44.98 & 0.51 & 1.11 & 43.45 & 0.112 \\
\hline 3 & D.P.N.3 & 0.43 & 39.75 & 0.52 & 1.32 & 42.76 & 0.104 \\
\hline 4 & D.P.N.4 & 0.38 & 46.74 & 0.54 & 1.09 & 45.46 & 0.101 \\
\hline 5 & D.P.N.5 & 0.41 & 39.56 & 0.49 & 1.34 & 44.46 & 0.104 \\
\hline 6 & D.P.N.6 & 0.39 & 41.53 & 0.51 & 1.25 & 42.46 & 0.109 \\
\hline 7 & D.P.N.7 & 0.38 & 44.76 & 0.47 & 1.15 & 42.86 & 0.110 \\
\hline 8 & D.P.N.8 & 0.27 & 45.54 & 0.50 & 1.36 & 40.54 & 0.111 \\
\hline 9 & D.P.N.9 & 0.36 & 43.67 & 0.49 & 1.24 & 42.57 & 0.102 \\
\hline 10 & D.P.N.10 & 0.35 & 40.63 & 0.54 & 1.12 & 38.35 & 0.145 \\
\hline 11 & D.P.N.11 & 0.38 & 38.85 & 0.47 & 1.61 & 46.75 & 0.109 \\
\hline 12 & D.P.N.12 & 0.44 & 47.58 & 0.51 & 1.07 & 38.35 & 0.101 \\
\hline 13 & D.P.N.13 & 0.40 & 39.64 & 0.52 & 1.46 & 42.35 & 0.105 \\
\hline 14 & D.P.N.14 & 0.39 & 40.56 & 0.53 & 1.25 & 45.37 & 0.113 \\
\hline 15 & D.P.N.15 & 0.41 & 43.43 & 0.49 & 1.09 & 39.98 & 0.105 \\
\hline & Average & 0.38 & 42.46 & 0.51 & 1.40 & 42.66 & 0.115 \\
\hline
\end{tabular}

*D.P.N $>$ Drug Addicted patient's nails samples 


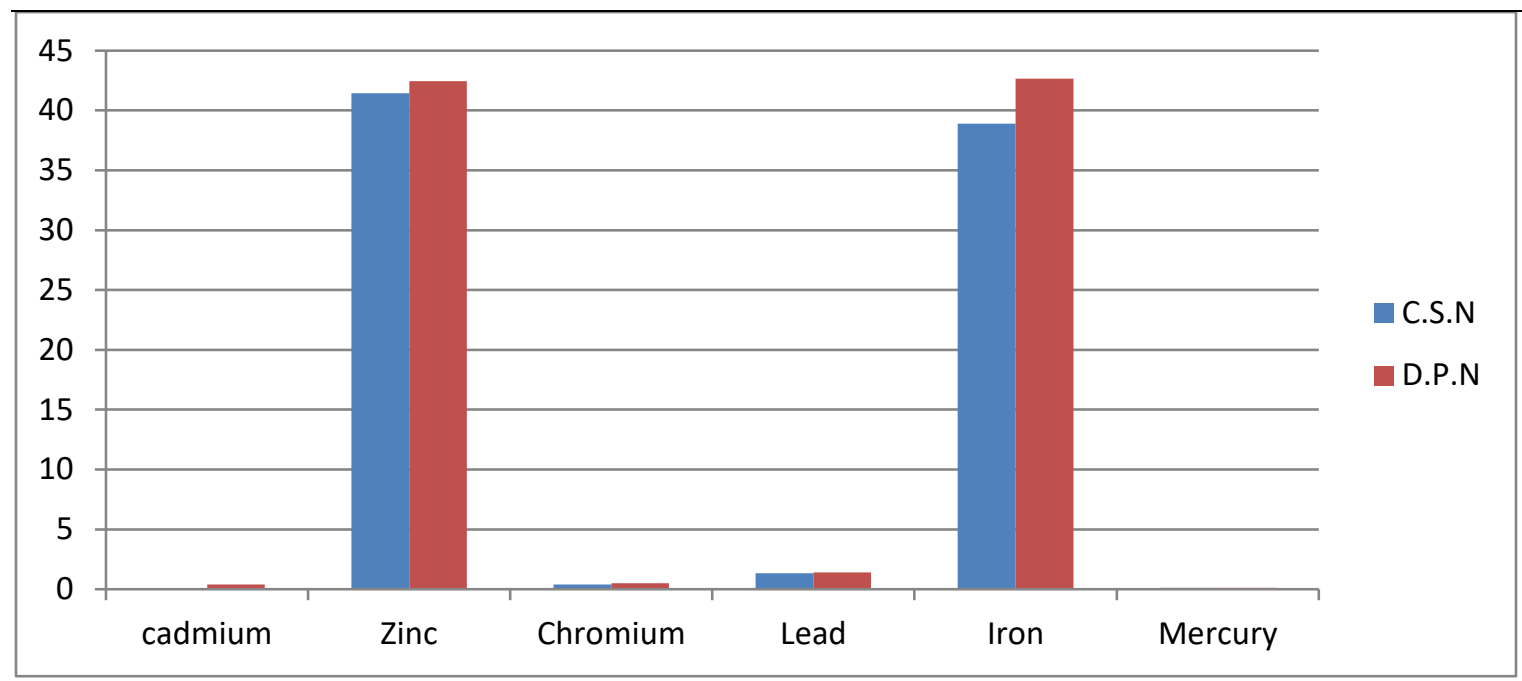

*D.P.H> Drug Addicted Patient's Hair Sample; *C.S.H> control samples of hair

Figure 3: Graphical illustration of Comparisons between Selected Metal Levels in control Nail samples and Nails samples of Drug-Addicted Patients

Iron $(\mathrm{Fe})$ is detected as the second-highest abundant metal in both hair and nail samples. A similar highest tendency for Fe was observed by (Naushad et al., 2014). This indicates that the concentration of metals in the nail is a function of metal concentration in the work environment or exposure, as reported by (Adulrahman et al., 2012). Another research has also explored the high value for Fe than other metals in the nail samples of children and adults (Okoro et al., 2015). Metabolic activity is absent in nails. Hence it acts as a reliable diagnostic tool for environmental contamination assessment, mainly drinking water (Muralidharan, 2013). A possible reason is that massive inputs of anthropogenic activities by man enrich $\mathrm{Fe}$ in the dietary source of man (Mudgal et al., 2010). Fig.3 represent a graphical illustration of comparisons between selected metal levels in control nail samples and nails samples of Drug-Addicted Patients

Lead $(\mathrm{Pb})$ was also detected in both types of samples, but the amount was relatively high in experimental samples than in the control group. Tanning industries are commonly found in Lahore, consequently high $\mathrm{Pb}$ content in hair and nail samples. Specific and different industries like gasoline, batteries, ceramic, paint and dyes, and bullets contribute their concentration in the environment (Lauwerys et al., 2001). Results showed that the $\mathrm{Pb}$ is the third most abundant metal found in healthy and drug-addicted patients, but its amount in the Drug addicted patients' hair was slightly high. Approximately $99 \%$ of the $\mathrm{Pb}$ bound to the hemoglobin of erythrocytes after absorption, and the vascular system circulates towards nails, hair, liver, kidney, and bone. $\mathrm{Pb}$ has a 30 days half-life in the blood, depending on the half-life of a RBC. These results are correlated with (Liang et al., 2017), who observed the following sequence $\mathrm{Pb}>\mathrm{Cr}>\mathrm{Hg}>\mathrm{Sb}>\mathrm{Cd}$ in hair and nail samples related to dietary habits (Jun-Fa, 2004; Pereira et al., 2004).

Chromium $(\mathrm{Cr})$ occurs as the seventh most abundant element of this nature with different oxidation states (Cervantes et al., 2001) and fourth abundant metal among selected six heavy metals in this study. Cr ions produced in the tanning process occur primarily in trivalent form; organic compounds convert them into hexavalent chromium states (Sarin and Pant 2006). The extensive use of $\mathrm{Cr}$ in various industrial processes like leather tanning has transformed it into a potential contaminant of air, soil, and water bio-accumulated and then biomagnified in the human body (Sánchez, 2001;Khasimet al. 1989).

Cadmium (Cd) content in the Drug- addicted patient samples was seen, while the amount of Cd is relatively low in the nail of healthy subjects. Cd is found in water sources present in the vicinity of metal mining and refining site, fertilizers industry, waste incineration, and dumping sites (Buchet, 1981). But the region where the samples were collected is not a mining or fertilizer industry site; thus, its amount is not too high. Cd showed a just slight sign of its presence in the samples. These results are similar to Liang et al. (2017), who observed the most negligible value for Cd in hair samples of China Inhabitants. Except smoking, humans are exposed to Cd via consumption of aquatic food, lettuce, spinach, organ meats, grains, nuts, sunflower seeds, and soybeans, in particular water contaminated with toxic heavy metals. It is reported that prostate cancer is caused by $\mathrm{Cd}$, followed by $\mathrm{Zn}$ and $\mathrm{Cr}$ in humans (Killileaet al., 2007). Chronic exposure to a low level of $\mathrm{Cd}$ is recognized as a risk to cancer and mortality (Nawrot, 2006). These results are contrary to (Kumakli et al., 2017) who calculated high concentrations for $\mathrm{Cd}(2.96 \mathrm{mg} / \mathrm{g})$ in hair sample of smokers, indicated that cigarette is a frequent source of Cd deposition in humans other than water (Kumakli et al., 2017). 
$\mathrm{Hg}$ was also detected, but its amount was too low and ignored in both control and experimental samples. These results are similar to Liang et al. (2017), who observed the least values for $\mathrm{Hg}(0.04$ to $0.87 \mathrm{mg} / \mathrm{kg})$ in hair samples of China inhabitants (Qin, 2004). Hg is frequently used in many products like cosmetics, meteorological equipment, batteries, thermometers, and barometers. Significant sources of mercury are mining and tanning industries that are not found in the Lahore region (Pilones et al., 2007). Hair and nails analysis as biomarkers demonstrated that diet also plays a significant role in accumulating heavy metals in the body (Batool et al., 2015).

\section{Conclusion}

The current study is conducted to analyze the heavy metals in hair and nail samples collected from Drug addicted patients in relation to drinking water facilities in Lahore, Pakistan. Results demonstrated high levels of heavy metals $(\mathrm{Zn}, \mathrm{Fe}, \mathrm{Pb}$, $\mathrm{Cr}, \mathrm{Cd}$, and $\mathrm{Hg}$ ) in Drug- addicted patients compared to healthy ones (control group). Heavy metals are responsible for serious health issues in the human body. Thus, administrative authorities should take serious notice to remove heavy metals from drinking water. Industrial effluents should be treated before pouring into natural water sources. There is also an instant need to bring awareness in the community about the hazards of heavy metals accumulated in the body via contaminated water.

\section{Acknowledgment}

The author is thankful to the Department of Chemistry, Government College University, Lahore, for providing the opportunity to conduct this research. Also grateful to Doctor Shazia Khursheed, Department of Chemistry, GCU Lahore, for her support and encouragement.

\section{Conflict of Interest}

It is declared that there is no conflict of interest between Authors

\section{References}

Abdelatey, L.M., Khalil, W. K., Ali, T. H., Mahrous, K. F. (2011). Heavy metal resistance and gene expression analysis of metal resistance genes in gram-positive and gram-negative bacteria present in egyptian soils. J. Appl. Sci. Environ. Sanit., $6,201-211$.

Abdulrahman, F. I., Akan, J. C., Chellube, Z. M., \& Waziri, M. (2012). Levels of heavy metals in human hair and nail samples from Maiduguri Metropolis, Borno State, Nigeria. World Environ, 2(4), 81-89.

Agrawal, S., Thomas, T., \& Mishra, M. K. (2020). Comparative Study of Heavy Metals Accumulation in the Nails of Drinkers and Non-Drinkers of River Water. Indian Journal of Forensic Medicine \& Toxicology, 14(3), 719.

Alabdula'aly, A. I., \& Khan, M. A. (2009). Heavy metals in cooler waters in Riyadh, Saudi Arabia. Environmental monitoring and assessment, 157(1), 23-28.

Apostoli, P. (2002). Elements in environmental and occupational medicine. Journal of chromatography B, 778(1-2), 63-97.

Barbosa Jr, F., Tanus-Santos, J. E., Gerlach, R. F., \& Parsons, P. J. (2005). A critical review of biomarkers used for monitoring human exposure to lead: advantages, limitations, and future needs. Environmental health perspectives, 113(12), 1669-1674.

Batool, F., S. Iqbal, K. W. Chan, M. I. Tariq, A. Shah and M. Mustaqeem. 2015. Concentrations of Heavy Metals in Hair and Nails of Young Pakistanis: Correlation with Dietary elements Environ. Forensic. 16:1-6.

Bibi, M., Hashmi, M. Z., \& Malik, R. N. (2016). The level and distribution of heavy metals and changes in oxidative stress indices in humans from Lahore district, Pakistan. Human \& experimental toxicology, 35(1), 78-90.

Buchet, J. P., Lauwerys, R., \&Roels, H. (1981). Urinary excretion of inorganic arsenic and its metabolites after repeated ingestion of sodium metaarsenite by volunteers. International archives of occupational and environmental health, 48(2), 111-118. 
Cervantes, C., Campos-Garcia, J., Devars, S., Gutiérrez-Corona, F., Loza-Tavera, H., Torres-Guzman, J. C., \& MorenoSánchez, R. (2001). Interactions of chromium with microorganisms and plants. FEMS microbiology reviews, 25(3), 335347.

Chao, H. P., Chang, C. C., \&Nieva, A. (2014). Biosorption of heavy metals on Citrus maxima peel, passion fruit shell, and sugarcane bagasse in a fixed-bed column. Journal of Industrial and Engineering Chemistry, 20(5), 3408-3414.

Chatt, A., \& Katz, S. A. (1998). Hair Analysis: Applications. The Biomedical and Environmental Sciences. New York, NY, USA: VCH Publishers.

Chen, X. C., Wang, Y. P., Lin, Q., Shi, J. Y., Wu, W. X., \& Chen, Y. X. (2005). Biosorption of copper (II) and zinc (II) from aqueous solution by Pseudomonas putida CZ1. Colloids and Surfaces B: Biointerfaces, 46(2), 101-107.

Chowdhury, S., Mazumder, M. J., Al-Attas, O., \& Husain, T. (2016). Heavy metals in drinking water: occurrences, implications, and future needs in developing countries. Science of the total Environment, 569, 476-488.

Gautam, R. K., Mudhoo, A., Lofrano, G., \&Chattopadhyaya, M. C. (2014). Biomass-derived biosorbents for metal ions sequestration: Adsorbent modification and activation methods and adsorbent regeneration. Journal of environmental chemical engineering, 2(1), 239-259.

Golasik, M., Przybyłowicz, A., Woźniak, A., Herman, M., Gawęcki, W., Golusiński, W., \&Piekoszewski, W. (2015). Essential metals profile of the hair and nails of patients with laryngeal cancer. Journal of Trace Elements in Medicine and Biology, 31, 67-73.

Haneke E (2015) Anatomy of the nail unit and the nail biopsy. In: Seminars in cutaneous medicine and surgery. Frontline Med Commun., 34 (2), 95-100.

Ibrahim, S. M. S. M., Abdelbagi, A. M., \&Sharf, A. E. S. A. E. (2014). Trace elements assessment in human nails in Eastern Sudan using atomic absorption spectroscopy. Journal of Analytical Sciences, Methods and Instrumentation, 2014.

Jun-Fa, Q. (2004). The upper limit of normal value of hair Pb, Cd, As, Hg in Chinese residents. Trace Elem. Sci, 4, 29-37.

Kaluza, J., Jeruszka, M., \&Brzozowska, A. (2000). Iron, zinc and copper status of elderly people living in warsaw district determined by hair analysis. RocznikiPanstwowego Zak AduHigieny, 52, 111-118.

Khasim, D. I., Kumar, N. V., \& Hussain, R. C. (1989). Environmental contamination of chromium in agricultural and animal products near a chromate industry. Bulletin of Environmental Contamination and Toxicology, 43(5).

Killilea, A. N., Downing, K. H., \&Killilea, D. W. (2007). Zinc deficiency reduces paclitaxel efficacy in LNCaP prostate cancer cells. Cancer letters, 258(1), 70-79.

Kumakli, H., A'ja, V. D., McDaniel, K., Mehari, T. F., Stephenson, J., Maple, L., \&Fakayode, S. O. (2017). Environmental biomonitoring of essential and toxic elements in human scalp hair using accelerated microwave-assisted sample digestion and inductively coupled plasma optical emission spectroscopy. Chemosphere, 174, 708-715.

Kumar, V., Abbas, A. K., \& Aster, J. C. (2013). Environmental and Nutritional Diseases. En: Robbins Basic Pathology, 9 , 269-307.

Lauwerys, R. R., \&Hoet, P. (2001). Industrial chemical exposure: guidelines for biological monitoring. CRC Press.

Liang, G., Pan, L., \& Liu, X. (2017). Assessment of typical heavy metals in human hair of different age groups and foodstuffs in Beijing, China. International journal of environmental research and public health, 14(8), 914. 
Loutfy, N., Fuerhacker, M., Tundo, P., Raccanelli, S., El Dien, A. G., \& Ahmed, M. T. (2006). Dietary intake of dioxins and dioxin-like PCBs, due to the consumption of dairy products, fish/seafood and meat from Ismailia city, Egypt. Science of the total environment, 370(1), 1-8.

Mohod, C. V., \&Dhote, J. (2013). Review of heavy metals in drinking water and their effect on human health. International Journal of Innovative Research in Science, Engineering and Technology, 2(7), 2992-2996.

Mudgal, V., Madaan, N., Mudgal, A., Singh, R. B., \& Mishra, S. (2010). Effect of toxic metals on human health. The Open Nutraceuticals Journal, 3(1).

Muralidharan, L. (2013) Nail as a Diagnostic Tool to Detect Heavy Metal Accumulation in Man Residing in Mumbai City and Their Impact on General Health. International Journal of Advanced Research, 1, 39-44.

Naushad, S. S., Lall, A. M., \&Charan, A. A. (2014). Determination of heavy metals in water of Ganga and Yamuna river basin in Allahabad. Asian Journal of Environmental Science, 9(2), 106-108.

Nawrot, T., Plusquin, M., Hogervorst, J., Roels, H. A., Celis, H., Thijs, L., \&Staessen, J. A. (2006). Environmental exposure to Cadmium and risk of cancer: a prospective population-based study. The lancet oncology, 7(2), 119-126.

Okoro, H. K., Alao, S. T., Adebayo, G. B., \& Basheer, K. A. (2015). Evaluation of heavy and trace metals in fingernails of young school children and adults in Ilorin, Kwara State, Nigeria. Journal of Applied Sciences and Environmental Management, 19(2), 319-324.

Pereira, R., Ribeiro, R., \& Goncalves, F. (2004). Scalp hair analysis as a tool in assessing human exposure to heavy metals (S. Domingos mine, Portugal). Science of the Total Environment, 327(1-3), 81-92.

Pilones, K., Lai, Z. W., \&Gavalchin, J. (2007). Prenatal $\mathrm{HgCl} 2$ exposure alters fetal cell phenotypes. Journal of immunotoxicology, 4(4), 295-301.

Qayyum, M. A., \& Shah, M. H. (2014). Comparative study of trace elements in blood, scalp hair and nails of prostate cancer patients in relation to healthy donors. Biological trace element research, 162(1), 46-57.

Rehman, K., Fatima, F., Waheed, I., \& Akash, M. S. H. (2018). Prevalence of exposure of heavy metals and their impact on health consequences. Journal of cellular biochemistry, 119(1), 157-184.

Rodrigues, J. L., Batista, B. L., Nunes, J. A., Passos, C. J., \& Barbosa Jr, F. (2008). Evaluation of the use of human hair for biomonitoring the deficiency of essential and exposure to toxic elements. Science of the Total Environment, 405(1-3), 370376.Sarin, V., \& Pant, K. (2006). Removal of chromium from industrial waste by using eucalyptus bark. Bioresource Technology, 97(1), 15-20.

Srogi, K. (2006). Hair analysis for monitoring environmental pollution and the resulting human exposure to trace metals: An overview. Environnement, Risques\&Santé, 5(5), 391-405.

Stepanova, N. V., Fomina, S. F., Valeeva, E. R., \&Ziyatdinova, A. I. (2018). Heavy metals as criteria of health and ecological well-being of the urban environment. Journal of Trace Elements in Medicine and Biology, 50, 646-651.

Yoshizawa, K., Rimm, E. B., Morris, J. S., Spate, V. L., Hsieh, C. C., Spiegelman, D., \& Willett, W. C. (2002). Mercury and the risk of coronary heart disease in men. New England Journal of Medicine, 347(22), 1755-1760. 